\title{
How Forests Think: Toward an Anthropology Beyond the Human. By Eduardo Kohn. 2013. University of California Press, Berkeley. 288 pp.
}

\author{
Katherine E. Flores ${ }^{1}$, Armando Medinaceli ${ }^{1}$, and Amanda M. Thiel ${ }^{1 *}$ \\ ${ }^{1}$ Department of Anthropology, Washington State University, Pullman, WA, USA. \\ *amanda.thiel@wsu.edu
}

Received February 24, 2016

OPEN ӘACCESS

Accepted June 8, 2016

DOI 10.14237/ebl.7.1.2016.550

Copyright (c) 2016 by the author(s); licensee Society of Ethnobiology. This is an open-access article distributed under the terms of the Creative Commons Attribution-NonCommercial 4.0 International Public License (https://creativecommons.org/licenses/by-nc/4.0), which permits non-commercial use, distribution, and reproduction in any medium, provided the original author and source are credited.

How Forests Think: Toward an Anthropology Beyond the Human offers an unconventional perspective in anthropology. Kohn uses arguments from animism (Philippe Descola), perspectivism (Eduardo Viveiros de Castro), and semiotics (Charles Sanders Peirce) to argue for a different anthropology-one that does not focus only on humans, but that identifies and analyzes animals and plants in terms of their own selves. This, coupled with how humans interact with these other beings, is what Kohn defines as an "anthropology beyond the human." To understand this idea, Kohn encourages us to explore what signs look like beyond the human. Kohn's theories are based on over four years of field experience immersed in the lives of the Quichua speaking Runa people of Ávila in Ecuadorian Amazonia - people strongly connected with different beings in the forest.

A central premise of How Forests Think is the notion of 'self.' Kohn equates selfhood with thinking, in the sense that if something, or someone (a broad category, and not limited to humans) experiences meaning, intention, purpose, function or significance, then this something or someone is "enchanted", or alive. Thus, a forest is alive and thinking, as is a dog, a jaguar, a peccary, and a plant. He expands this discussion of selfhood by explaining life as a sign process in which-developing and quoting the thinking of Charles Peirce-anything alive is "something... [that] stands to somebody, for something in some respect or capacity" (Peirce 1992:228, cited in Kohn, p. 74). From here, Kohn suggests that there are many different kinds of selves, from the "physically bounded organism" to one that is "distributed over bodies" (p. 75), such as a group of people or an ant colony. The definition of selfhood he proposes holds because, to a particular crowd of people, for example, there may be a unified purpose or function amongst them and their presence represents something. Kohn weaves these assertions into a broader semiotic discourse on what it means to think, be alive and to relate with other thinking, animate selves. He calls this an "ecology of selves" (p. 78), evident in the dynamism of the forest around Ávila and the interrelationship of humans with animals, plants, and spirits therein.

Kohn's "trans-species pidgin" discussion is one of the book's strongest and most ethnographic chapters. According to Kohn, a trans-species pidgin is the language humans speak when talking to living entities, primarily dogs but also including forests. This language allows the Runa to communicate with their dogs directly and to interpret dogs' dreams via the vocalizations dogs make while sleeping. Kohn's abstract discussions of "self" become clearer as this particular chapter unfolds. The pidgin's structure and application are indicators of how the Runa conceptualize their role in humanity. Considering dogs' and forests' languages and how they are transmitted and exist within Runa culture is an aspect of the anthropological "beyond" which Kohn endorses. He argues that these entities sustain humans and need to have their own anthropological attention.

Runa people have an atypical relationship with dogs. They ignore dogs, not even feeding them, until they are mature, seemingly living in separate worlds. Yet, humans and dogs nevertheless entangle with one another daily in the home or village, and in interactions in their physical environment, as well as through dreaming and language. The Runa communicate with dogs orally, and even give them hallucinatory plant 
mixtures to counsel them. They give dogs tasks or behavioral commands; they instruct them to chase and hunt wild game, but not to chase domestic animals. They say that dogs, like men, should not be violent, nor should they bite or bark loudly at humans. Kohn implies that dogs can become human, to some extent, and can also acquire jaguars' ultimate predatory qualities. For the Runa, dogs are the spiritual masters of jaguars, who in turn, are the masters of the forest animals. Runa thus express that, "what we think of as a jaguar is actually a dog" ( $p$. 137).

How Forests Think, while attempting to demonstrate a new vision of anthropology, at times aligns closely with ethnobiology, discussing the interrelationship of the Ávila Runa with forests, dogs, jaguars, peccaries, and other forest inhabitants. Kohn offers an interaction that goes beyond the utilitarian to include the spiritual and mental interactions of people with their environment, and by offering an analysis of the interactions of other non-human beings, and attempting to understand how they perceive their own relationship with the forest and with humans. Ethnobiologists, therefore, may find How Forests Think appealing for its potential to transform cultural theory as it relates with the environment. Kohn calls for an anthropology that considers other beings along with humans as part of a whole environmental unit, one that is full of interactions within and between actors. Readers unfamiliar with post-modernist anthropological theory and its characteristic writing style should take heed. Kohn's writing and the topics he discusses are philosophical in nature and may be challenging to comprehend at first glance. It may be helpful for future readers to read his American Ethnologist article, 'How Dogs Dream: Amazonian Natures and The Politics of Transspecies Engagement' before starting this book. Novice interpretivists should not take this advice as a warning to avoid this book; rather, they need to be prepared to work through the confusion they may initially feel as they read.

Although his work is not traditionally ethnographic in nature, Kohn makes a powerful contribution to anthropological theory and creates a pathway for the expansion of an "anthropology beyond the human." Understanding the relationships humans and other biota maintain are essential to anthropological holism and can provide insight into a culture's worldviews and behavior motives. Kohn forces the reader to reconsider what $\mathrm{s} /$ he considers a "self" and how they fit into his/her world. Overall, this book is a welcomed challenge and may be unexpectedly useful for scholars interested in ecology or cognition.

\section{References Cited}

Kohn, E. 2007. Hows Dogs Dream: Amazonian Natures and the Politics of Transspecies Engagement. American Ethnologist 34:3-24.

Peirce, C. S. 1992. The Essential Peirce: Selective Philosophical Writings, vol. 1. Indiana University Press, Bloomington, IN. 